\title{
Colitis and colonic mucosal barrier dysfunction
}

\author{
K R Gardiner, N H Anderson, B J Rowlands, A Barbul
}

\begin{abstract}
Trauma, infection, neoplasia, and inflammation can all disrupt the intact intestinal mucosal barrier to intraluminal bacteria and bacterial antigens. This study investigated the relation between colonic inflammation and colonic mucosal barrier function in three experimental models of colitis. There were significantly increased systemic endotoxin concentrations in rats with acetic acid $(7.5(1.7-119.5) \mathrm{pg} / \mathrm{ml})$, ethanol $(13 \cdot 7(0-111 \cdot 2) \mathrm{pg} / \mathrm{ml})$, and hapten induced $(14.4(5-31 \cdot 1) \quad \mathrm{pg} / \mathrm{ml})$ colitis compared with saline controls $(3 \cdot 3$ $(0-13 \cdot 7) \mathrm{pg} / \mathrm{ml})$. Data expressed as median (range). There were significant correlations between the systemic endotoxin concentration and both the severity of colitis and of illness in acetic acid induced colitis. A significant increase in colonic permeability to ${ }^{14} \mathrm{C}$-polyethylene glycol was shown in rats with acetic acid (3.42 $(1 \cdot 36-5 \cdot 63) \%)$ and hapten induced colitis $(2.86(1.03-8 \cdot 10) \%)$ compared with saline controls $(1.20 \quad(0 \cdot 67-1 \cdot 36) \%)$. Data expressed as median (range) of percentage of the intracolonic bolus excreted in urine. There was a significant positive correlation between the severity of colitis and $\%$ colonic permeability to ${ }^{14} \mathrm{C}$-polyethylene glycol. This and other studies provide evidence that mucosal barrier dysfunction is a feature of colitis irrespective of aetiology or species. Such barrier dysfunction may be responsible for the systemic inflammatory response and complications seen in patients with inflammatory bowel disease.

(Gut 1995; 37: 530-535)
\end{abstract}

Keywords: acetic acid, ethanol, hapten, permeability, endotoxaemia.

Departments of

Surgery

K R Gardiner

B J Rowlands

and Pathology

$\mathrm{N} H$ Anderson

The Queen's University of Belfast

Department of Surgery, Sinai Hospital and The Johns Hopkins Medical Institutions, Baltimore, USA

A Barbul

Correspondence to: Mr K R Gardiner, Department of Surgery, The Queen's University of Belfast, Institute of Clinical Science, Grosvenor Road, Belfast BT12 6BJ.

Accepted for publication 8 February 1995

The occurrence of ulcerative colitis in a location that normally harbours a luxuriant bacterial population and the disturbances in intestinal bacterial flora seen in patients with Crohn's or ulcerative colitis ${ }^{12}$ have suggested a role for enteric bacteria in the pathogenesis of these diseases. Blood and tissue culture studies $^{3-5}$ and reports of increased circulating concentrations of antimicrobial antibodies ${ }^{6}$ provide evidence that bacterial translocation occurs in patients with active inflammatory bowel disease (IBD). There is also evidence that products of enteric bacteria penetrate the intestinal wall in patients with IBD. Portal and systemic endotoxaemia have been repeatedly reported in both Crohn's disease and ulcerative colitis. ${ }^{7-10}$ In addition, there are reports of significantly increased circulating titres of antibodies to the core region of bacterial endotoxin, ${ }^{10}$ to lipid $A,{ }^{11}$ and to peptidoglycan-polysaccharide complexes ${ }^{12}$ in patients with active IBD.

It has been suggested that absorption of these enteric bacterial products contributes to the systemic clinical and biochemical features of IBD. ${ }^{913} 14$ Indeed, systemic endotoxin concentrations correlate positively with the presence and extent of intestinal ulceration and with disease activity in IBD. ${ }^{7-10}$ Systemic endotoxaemia also occurs, however, when the intestinal mucosal barrier is damaged by bacterial enteritis, helminthiasis, colonoscopy, neoplasms, and ischaemia. ${ }^{15-19}$ It is unclear whether the finding of extraintestinal bacteria and bacterial products in patients with IBD is of clinical significance or is simply a reflection of a generalised increase in intestinal permeability. $^{20}$

The aim of these studies was to investigate the relation between colonic inflammation and dysfunction of the colonic mucosal barrier in three experimental models of colitis (hapten, acetic acid, and ethanol induced colitis). Colonic permeability was assessed using the hydrophilic macromolecule polyethylene glycol (MW 4000) and translocation of enteric bacterial endotoxin estimated by the measurement of systemic endotoxaemia using the Limulus assay.

\section{Methods}

STUDY 1: COLONIC INFLAMMATION AND SYSTEMIC ENDOTOXAEMIA

\section{Animals}

Male Wistar rats (weighing $300-400 \mathrm{~g}$ ) were housed in groups of four rats per cage in a room with controlled temperature $\left(22^{\circ} \mathrm{C}\right)$ and light-dark cycle $(12 \mathrm{~h}: 12 \mathrm{~h})$. Standard rat pelleted formula and tap water were provided ad libitum. This study was carried out under the

\section{Intracolonic instillation technique}

After a 16 hour fast from food, rats were sedated by an intramuscular injection of $0.1 \mathrm{ml}$ Hypnorm (fentanyl citrate $0.315 \mathrm{mg} / \mathrm{ml}$, fluanisone $10 \mathrm{mg} / \mathrm{ml}$; Janssen Pharmaceutical, Oxford, UK) and $0.25 \mathrm{mg}$ diazepam (Belfast) and weighed. A 5 Fr polypropylene catheter (Bardic Feeding Tube 1732, Bard, Sunderland, England) was lubricated with jelly and inserted into the colon through the anal canal for a distance of $10-12 \mathrm{~cm}$ to lie at or just proximal to the splenic flexure. At this point, the inducing agent was instilled. The catheter 
was then flushed with $0.5 \mathrm{ml}$ air to expel any inducing agent remaining in the catheter. After instillation, the rats were supported in a supine Trendelenburg position until recovery from sedation to prevent immediate anal leakage of the instillate.

\section{Intracolonic instillates}

Animals were randomised to receive, by intracolonic instillation, either: (a) $0.5 \mathrm{ml}$ normal saline (control) $(n=16)$; (b) $0.5 \mathrm{ml} 50 \%$ ethanol $(n=16)$; (c) $1 \mathrm{ml} 10 \%$ acetic acid followed 15 seconds later by $5 \mathrm{ml} \mathrm{N}$ saline $(n=16)$; or (d) $20,25,30,35$, or $40 \mathrm{mg} 2,4,6$,trinitrobenzenesulphonic acid (TNBS) mixed with $0.25 \mathrm{ml} 30 \%$ ethanol ( $\mathrm{n}=8 /$ group).

\section{Methods of assessment}

Behaviour and appearance of animals were observed throughout the study period of eight days. At completion of the study, systemic blood was collected under sedation for plasma endotoxin estimation (Limulus assay), ${ }^{21}$ serum albumin, lactate, and alkaline phosphatase activity. The colon was then removed for assessment using a colon macroscopic score (0-10) as previously described. ${ }^{21}$ The colonic tissue was fixed using Brunnels primary fixative (Laboratory Supplies and Instruments, Antrim, UK), processed by conventional methods, and embedded in paraffin wax. Five $\mu \mathrm{m}$ sections were stained by haematoxylin and eosin and examined using a Leitz Laborlux $\mathrm{K}$ microscope.

STUDY 2: COLONIC INFLAMMATION AND COLONIC PERMEABILITY

Animals

Male Sprague-Dawley rats (Harlan SpragueDawley, Indianapolis, IN, USA), weighing 300-350 g, were used in this study. A complete pelleted laboratory chow and tap water were provided ad libitum. This study adhered to National Institute of Health (USA) guidelines for animal experimentation.

\section{Intracolonic instillation technique}

As before, except animals were anaesthetised by an intraperitoneal injection of pentobarbital sodium $5 \mathrm{mg} / 100 \mathrm{~g}$ bw (Wyeth Laboratories, Philadelphia, PA).

\section{Intracolonic instillates}

Animals ( $n=6 /$ group) were randomised to receive by intracolonic instillation either: (a) $0.5 \mathrm{ml} \mathrm{N}$ saline (control); (b) $0.5 \mathrm{ml} 50 \%$ ethanol; (c) $1 \mathrm{ml} \mathrm{10 \%} \mathrm{acetic} \mathrm{acid} \mathrm{followed} 15$ seconds later by $5 \mathrm{ml} \mathrm{N}$ saline; or (d) $30 \mathrm{mg}$ $2,4,6,-$ TNBS mixed with $0.25 \mathrm{ml} 30 \%$ ethanol.

\section{Methods of assessment}

Appearance and behaviour of animals and severity of colonic inflammation were assessed as above. Colonic permeability was assessed, eight days after the initial intracolonic instillation, by measuring urinary excretion of an intraluminally administered bolus of trace labelled polyethylene glycol (PEG) 4000.

Intracolonic instillation of ${ }^{14} C-P E G 4000$ - the animals were re-anaesthetised with an intraperitoneal injection of pentobarbital sodium as above. A 3-0 silk purse string suture was inserted around the anal canal. A 5 FR polypropylene catheter (Bardic feeding tube 1732, Bard, Sunderland, UK) was lubricated with jelly and inserted into the anal canal. Some $0.5 \mathrm{ml}$ of a $100 \mu \mathrm{M}$ solution of PEG (MW 4000) trace labelled with $5 \mu \mathrm{Ci}$ ${ }^{14} \mathrm{C}-\mathrm{PEG}$ was instilled into the colon through the catheter. After removal of the catheter, the anal canal was closed by tying the purse string suture. Immediately after intracolonic instillation, the rats were given a subcutaneous injection of normal saline ( $5 \mathrm{ml} / 100 \mathrm{~g} \mathrm{bw})$ and placed in individual collection cages for collection of urine. Access to tap water was provided ad libitum.

Excretion of ${ }^{14} C-P E G$ - after 12 hours, urine volume was measured and the urine centrifuged for 10 minutes at $500 \mathrm{~g}$ at $4^{\circ} \mathrm{C}$. Three $500 \mu \mathrm{l}$ aliquots were prepared for scintillation counting by the addition of $15 \mathrm{ml}$ of a scintillation cocktail (BIOFLUOR, New England Nuclear, Boston, MA).

Measurement of circulating ${ }^{14} C-P E G$ - after a further intraperitoneal injection of pentobarbital sodium as before, systemic blood was collected from each animal by direct cardiac puncture. Two $100 \mu \mathrm{l}$ blood samples were placed in glass scintillation counting vials; $0.5 \mathrm{ml}$ of tissue solubiliser (PROTOSOL, New England Nuclear, Boston, MA, USA) and $100 \%$ ethanol $(1: 2 \mathrm{vol} / \mathrm{vol})$ were added. The vials were incubated in a shaking water bath at $55^{\circ} \mathrm{C}$ for one hour. Samples were then treated with $0.5 \mathrm{ml}$ of $30 \%$ hydrogen peroxide and incubated at $55^{\circ} \mathrm{C}$ for an additional 30 minutes. After cooling to room temperature, $15 \mathrm{ml}$ of scintillation cocktail (BIOFLUOR, New England Nuclear, Boston, MA) were added and the vials shaken vigorously.

Determination of radioactivity $-{ }^{14} \mathrm{C}-\mathrm{PEG}$ content of urine and blood samples were determined using a liquid scintillation counter (Tricarb C2425, Packard Instruments, Downers Grove, IL, USA). Counting efficiencies were determined using the internal standard method.

Calculations - systemic concentration of ${ }^{14} \mathrm{C}-\mathrm{PEG}$ is expressed as $\mathrm{cpm} / \mathrm{ml}$. The colonic permeability $(\%)$ is calculated as:

$$
\frac{\mathrm{Uv} \times \mathrm{Uc} \times 100}{\mathrm{Iv} \times \mathrm{Ic}}
$$

where Uv and Uc are urine volume $(\mathrm{ml})$ and concentration $(\mathrm{cpm} / \mathrm{ml})$ and $\mathrm{Iv}$ and Ic are the volume ( $\mathrm{ml})$ and concentration of the instillate $(\mathrm{cpm} / \mathrm{ml})$ respectively.

\section{Data analysis}

Data are expressed as mean (SEM) or median (range) where appropriate. The results were 
TABLE I Laboratory assessment of illness severity in experimental colitis

\begin{tabular}{lrlll}
\hline Instillate & No & Lactate $($ mmoll $)$ & Alkaline phosphatase $($ Un) & Albumin $(g /)$ \\
\hline N saline & 16 & $1 \cdot 35(0 \cdot 07)$ & $115 \cdot 3(7 \cdot 0)$ & $29 \cdot 3(0 \cdot 3)$ \\
Ethanol & 16 & $1.94(0 \cdot 26)$ & $182 \cdot 7(12 \cdot 2) \dagger$ & $26 \cdot 3(0 \cdot 3)$ \\
Acetic acid & 16 & $3 \cdot 31(0 \cdot 44)^{\star}$ & $240 \cdot 4(16 \cdot 5) \dagger$ & $25 \cdot 3(0 \cdot 9) \ddagger$ \\
TNBS 35 mg & 8 & $3 \cdot 58(0 \cdot 58) \dagger$ & $170 \cdot 4(15 \cdot 6) \dagger$ & $24 \cdot 6(0 \cdot 7) \ddagger$ \\
\hline
\end{tabular}

Data expressed as mean (SEM).

Lactate $25.3 p<0.001$; alkaline phosphatase $27.4 p<0.001$; albumin $25.4 p<0.001$ (ANOVA). Lactate $v$ saline: ${ }^{\star}=\mathrm{p}<0.01$ (Student's $t$ test). Alkaline phosphatase $v$ saline: $\dagger=\mathrm{p}<0.005$

(Student's $t$ test). Albumin $v$ saline: $\ddagger=\mathrm{p}<0.05$ (Student's $t$ test).

entered onto a Macintosh LC computer (Apple, Cupertino, CA) and analysed using analysis of variance, Kruskal-Wallis test, Mann-Whitney U test, Student's $t$ test, and Spearman rank test (Statworks). Probabilities less than 0.05 were considered significant.

\section{Results \\ STUDY 1: COLONIC INFLAMMATION AND SYSTEMIC ENDOTOXAEMIA}

\section{Assessment of illness}

There was no change in behaviour or appearance of animals after intracolonic instillation of normal saline. Animals treated with ethanol, acetic acid or TNBS/ethanol showed weight loss, reduced fluid and food intake during the first 24 hours, diarrhoea, piloerection, lack of preening, and a reduced level of activity. There were significant increases in serum lactate concentration (acetic acid and TNBS groups) and in serum alkaline phosphatase activity (ethanol, acetic acid, and TNBS groups) and significant decreases in serum albumin concentration (acetic acid and TNBS groups) when compared with saline controls (Table I).

\section{Colonic assessment}

Ethanol instillation resulted in mucosal ulceration with overlying adherent slough, thickening of the colonic wall but little in the way of serosal reaction. On histological examination, there was an acute superficial ulceration involving the mucosa and submucosa with a mixed acute inflammatory infiltrate composed mainly of neutrophils and lymphocytes.

Acetic acid instillation resulted in pericolic wrapping of intraperitoneal fat, small intestine and often the spleen and a diffuse mucosal ulceration. Gross dilatation of the distal colon

TABLE II Body weight gain, colonic inflammation assessment, and systemic endotoxaemia in experimental colitis

\begin{tabular}{|c|c|c|c|c|}
\hline Instillate & No & $\begin{array}{l}\text { Body weight } \\
\text { gain }(g) \\
\text { Mean (SEM) }\end{array}$ & $\begin{array}{l}\text { Colon macroscopic } \\
\text { score (CMS) } \\
\text { Median (range) }\end{array}$ & $\begin{array}{l}\text { Systemic endotoxin } \\
\text { concentration ( } \mathrm{pg} / \mathrm{ml} \text { ) } \\
\text { Median (range) }\end{array}$ \\
\hline $\mathrm{N}$ saline & 16 & $16 \cdot 5(2 \cdot 0)$ & $0.5(0-1)$ & $3 \cdot 3(0-13 \cdot 7)$ \\
\hline Ethanol & 16 & $-1.9(6.5)$ & $6(4-9)^{\star}$ & $13 \cdot 7(0-111 \cdot 2)^{\star}$ \\
\hline Acetic acid & 16 & $-9 \cdot 6(6.9)^{\star}$ & $6(5-10)^{\star}$ & $7.5(1.7-119 \cdot 5)^{\star}$ \\
\hline \multicolumn{5}{|l|}{ TNBS (mg) } \\
\hline 20 & 8 & $-12 \cdot 4(9 \cdot 8)^{\star}$ & $4 \cdot 5(1-5)^{\star}$ & $8 \cdot 5(0-45 \cdot 7)$ \\
\hline 25 & 8 & $2 \cdot 3(7 \cdot 3)$ & $5(3-7)^{\star}$ & $7.9(0-51.9)$ \\
\hline 30 & 8 & $-4 \cdot 1(7 \cdot 4)^{\star}$ & $5(1-9)^{\star}$ & $5 \cdot 6(0-54 \cdot 4)$ \\
\hline 35 & 8 & $7 \cdot 7(8 \cdot 1)$ & $5(4-10)^{\star}$ & $14 \cdot 4(5-31 \cdot 1)^{\star}$ \\
\hline 40 & 8 & $-15.9(9.5)^{\star}$ & $5(1-9)^{\star}$ & $5 \cdot 6(0-57 \cdot 3)$ \\
\hline
\end{tabular}

Body weight gain $17 \cdot 3 \mathrm{p}=0.016$; CMS $36 \cdot 1 \mathrm{p}<0.001$; systemic endotoxin concentration 13.2 $\mathrm{p}=0.06$ (Kruskal-Wallis). Body weight gain $v$ saline: ${ }^{\star}=\mathrm{p}<0.05$ (Student's $t$ test). CMS $v$ saline: ${ }^{\star}=\mathrm{p}<0.05$ (Mann-Whitney). Systemic endotoxin concentration $v$ saline: ${ }^{\star}=\mathrm{p}<0.05$ (Mann-Whitney). resembling megacolon was also seen in some animals. Histological examination showed mucosal necrosis resulting in an acellular cast and infiltration of the submucosa and muscularis propria by a dense inflammatory infiltrate. Early submucosal fibrosis was apparent. The mucosa adjacent to the ulcer contained occasional crypt abscesses.

TNBS in ethanol instillation was associated with inflammation, ulceration, and thickening of the bowel wall extending from splenic flexure to the rectum. Segmental pericolic accumulations of mesenteric fat and fibrinous adhesions to the small bowel, spleen or stomach were frequently seen. Incomplete bowel obstruction with proximal dilatation was also occasionally seen. Some rats displayed grossly distended colons without obstruction or perforation (megacolon). Histological examination showed broad based mucosal ulcers with a surface layer of necrotic ulcer slough. Occasional islands of regenerative mucosa were present. The inflammatory infiltrate associated with the ulcers was mixed consisting of neutrophils, eosinophils, lymphocytes, and plasma cells and extended through the full thickness of the bowel wall. Occasional epithelioid granulomata were seen in the ulcer base.

Significant colonic damage was found in the groups instilled with acetic acid, ethanol or TNBS when compared with saline controls (Table II). There was a significant positive correlation between the dose of TNBS and the severity of the colonic damage as measured by the colonic macroscopic score (CMS) $\left(r_{\mathrm{s}}=0.391 ; \mathrm{p}=0.014\right.$ Spearman rank $)$.

Colonic inflammation and illness severity

There was a negative correlation between CMS and weight gain in both the ethanol $\left(r_{\mathrm{s}}=-0.67 ; \mathrm{p}=0.004\right)$ and acetic acid $\left(r_{\mathrm{s}}=-0.45 ; \mathrm{p}<0.05\right)$ groups. In the TNBS group there was a positive correlation between CMS and serum lactate concentration $\left(r_{\mathrm{s}}=0.562 ; \mathrm{p}=0.012\right)$ and a negative correlation between CMS and the serum albumin concentration $\left(r_{\mathrm{s}}=-0.788 ; \mathrm{p}<0.001\right)$.

\section{Systemic endotoxaemia}

Systemic endotoxin concentrations were significantly higher in the ethanol, acetic acid, and $35 \mathrm{mg}$ TNBS groups compared with saline controls (Table II).

\section{Colon inflammation and endotoxaemia}

There was a significant correlation of the systemic endotoxin concentration with the CMS in the acetic acid group $\left(r_{\mathrm{s}}=0.51\right.$; $\mathrm{p}=0.04$ ) but not in the ethanol or TNBS groups.

\section{Severity of illness and endotoxaemia}

There was a significant correlation of the systemic endotoxin concentration with serum lactate $\left(r_{\mathrm{s}}=0.66 ; \mathrm{p}=0.01\right)$ and serum albumin 


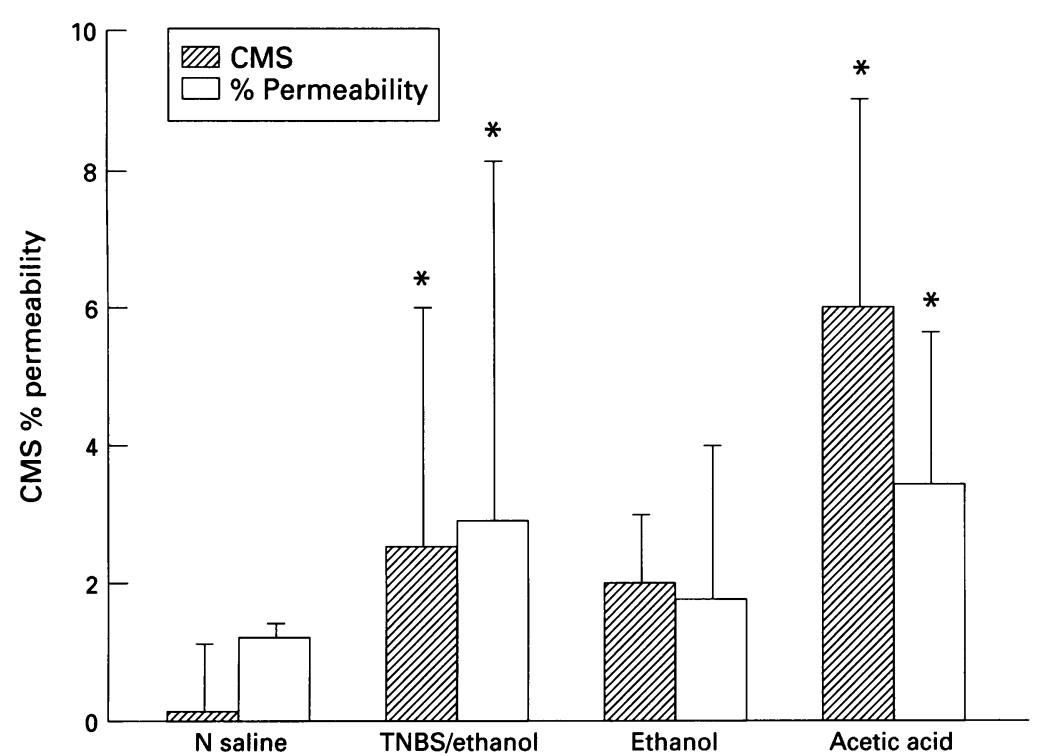

Figure 1: Colonic permeability to ${ }^{14} C-P E G 4000$ in experimental colitis. CMS $15 \cdot 55$ $p=0.001 ; \%$ permeability $8.55 p=0.036$ (Kruskal-Wallis). CMS v saline: ${ }^{\star}=p<0.05$ (Mann-Whitney). \% permeability v saline: ${ }^{\star}=p<0.05$ (Mann-Whitney).

$\left(r_{\mathrm{s}}=-0.59 ; \mathrm{p}=0.04\right)$ concentrations in the acetic acid group.

\section{STUDY 2: COLONIC INFLAMMATION AND} COLONIC PERMEABILITY

\section{Assessment of illness}

The appearance and behaviour of the animals in the different groups were as described before.

\section{Colonic assessment}

Instillation of TNBS/ethanol or of acetic acid, but not of ethanol, induced significant colon damage in comparison with controls (Fig 1). There was a significantly more severe colitis in the group receiving acetic acid.

\section{Colonic permeability to ${ }^{14} \mathrm{C}-\mathrm{PEG} 4000$}

Eight days after induction of colitis by intracolonic instillation of TNBS or of acetic acid there was a significant increase in colonic permeability as assessed by urinary excretion of ${ }^{14} \mathrm{C}-\mathrm{PEG} 4000$ given by intracolonic instillation (Fig 1). There was no significant

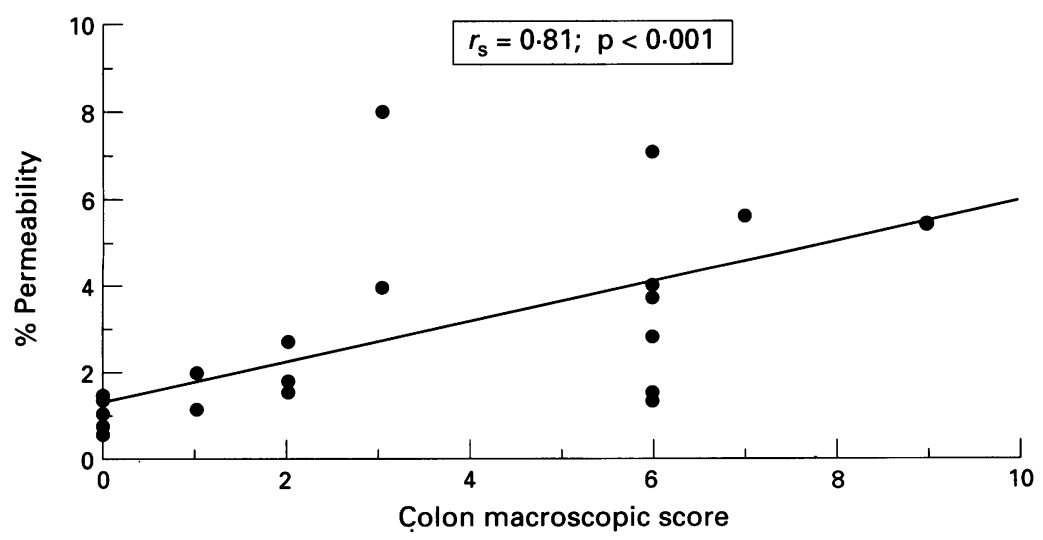

Figure 2: Colonic permeability and the colon macroscopic score (CMS) in experimental colitis. difference (median (range)) in the systemic concentrations of ${ }^{14} \mathrm{C}$-PEG 4000 between the different treatment groups ( $\mathbf{N}$ saline 334 (215-392); TNBS/ethanol 209 (185-398); ethanol 260 (253-335); acetic acid 327 (293-370) $\mathrm{cpm} / \mathrm{ml} ; \mathrm{p}=0.069$ Kruskal-Wallis).

\section{Colonic inflammation and permeability to} ${ }^{14} C-P E G 4000$

There was a significant positive correlation between the CMS and the \% colonic permeability to ${ }^{14}$ C-PEG $4000\left(r_{\mathrm{s}}=0.81, \mathrm{p}<0.001\right.$; Spearman rank) (Fig 2).

\section{Discussion}

The intestinal epithelium forms a vital barrier against the penetration of antigenic compounds into the intestinal tissue and systemic circulation. Derangement of mucosal barrier function may occur as a result of the use of non-steroidal anti-inflammatory analgesics, antibiotics or because of bacterial infection. The permeable mucosa may then permit absorption of microbial and dietary antigens and initiate an inflammatory reaction or perpetuate and potentiate IBD. ${ }^{22}$

Indirect evidence for dysfunction of the intestinal mucosal barrier in patients with IBD is provided by reports of increased concentrations of circulating immune complexes and antibodies to dietary and bacterial antigens, and the improvement in disease activity in Crohn's disease that follows bowel rest. ${ }^{6} 23$ Dysfunction of the mucosal barrier is most often described by demonstration of increased passive penetration of the intestinal barrier by non-charged macromolecules (permeability) or by detecting the extraintestinal migration of gut bacteria or endotoxin (translocation). ${ }^{24} 25$

In these studies, translocation of bacterial endotoxin and intestinal permeability to the hydrophilic probe polyethylene glycol were studied in three experimental models of colitis. Morris et $a l^{26}$ have described an immunological model where colitis is induced by an intracolonic instillation of ethanol to break down the mucosal barrier in combination with $2,4,6,-$ TNBS. This TNBS model of colitis has clinical and pathological similarities to Crohn's colitis $^{26}$ and has been extensively investigated. ${ }^{21}$ 27-29 In addition, two chemically induced models of acute colitis (acetic acid and ethanol models) were studied as these can also be induced in the rat by a similar route of administration. ${ }^{30} 31$

In the first study, intracolonic instillation of ethanol, acetic acid or of TNBS resulted in very similar 'clinical' features with diarrhoea and decreased weight gain predominating. Among the laboratory tests, significant increases in serum lactate concentration and alkaline phosphatase activity and a significant decrease in serum albumin concentration were found in both TNBS and acetic acid induced colitides when compared with controls. TNBS instillation resulted in a variable, transmural inflammation with pericolic adhesions. Intracolonic instillation of ethanol or of acetic acid 
produced a more diffuse, consistent, and superficial ulceration than seen after TNBS. There was a significant positive correlation between the dose of TNBS instilled and the CMS. The severity of the colitis showed significant correlations with the serum lactate concentration (TNBS), serum albumin concentration (TNBS), and weight gain (acetic acid, ethanol).

Significant systemic endotoxaemia was found in all the models when compared with controls. In acetic acid induced colitis, there were also significant correlations between the systemic endotoxin concentration and the serum concentrations of lactate (positive) and albumin (negative). Systemic endotoxaemia has been described in three other models of colitis: carrageenan and formalin/lipopolysaccharide induced colitis in the rabbit ${ }^{32} 33$ and in spontaneous haemorrhagic enterocolitis in the dog. ${ }^{34}$ Systemic endotoxaemia was seen in $87 \%$ rabbits with carrageenan induced colon ulceration and found to correlate with the presence, and extent, of ulceration. ${ }^{32}$

In the second study, the effect of induction of colitis on colonic permeability was studied using the hydrophilic probe PEG. PEG was chosen for this study as it is inert, non-toxic, non-immunogenic, not degraded by bacteria, and rapidly cleared in a non-metabolised form. ${ }^{35}$ The molecular size of PEG 4000 polymers restricts passive diffusion and is thought to more accurately reflect the transport of larger macromolecules. ${ }^{36}$ In this study, induction of colitis by intracolonic instillation of TNBS or of acetic acid resulted in a significant increase in colonic permeability to PEG 4000. A significant positive correlation was found between severity of colonic inflammation (as measured by CMS) and colonic permeability. Increased colonic permeability to PEG compared with controls, has also been reported in an immune complex model of colitis in rabbits (PEG 4000), ${ }^{36}$ in carrageenan induced colitis in the guinea pig (PEG$900),{ }^{37}$ and after perfusion of the rabbit colon with bile salts or hydroxy fatty acids (PEG 4000). ${ }^{38} 39$ Renal clearance of PEG 4000 is rapid and this may account for the low serum concentrations noted in this study and the lack of difference between colitic and control rats. ${ }^{36}$

In IBD, as in these animal studies, the degree of intestinal permeability has been correlated with disease severity. In patients with ulcerative colitis, there was increasing plasma to lumen clearance of ${ }^{51} \mathrm{Cr}$-EDTA with increasing extent of colitis. ${ }^{40} \mathrm{~A}$ significant positive correlation has been shown between intestinal permeability to hydrophilic probes

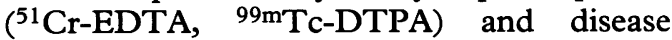
activity in both ulcerative colitis and Crohn's disease patients. ${ }^{4041}$ In addition, Gomes et $a l^{42}$ found that $89 \%$ of patients with active Crohn's disease compared with $13 \%$ patients with inactive disease had abnormal intestinal permeability to lactulose.

In summary, systemic endotoxaemia occurs in three rat (ethanol, acetic acid, and ethanol) and two rabbit models of colitis (carrageenan and formalin-lipopolysaccharide) ${ }^{32} 33$ as well as in spontaneous human ${ }^{7-10}$ and canine IBD. ${ }^{34}$ Translocation of enteric bacteria to extraintestinal sites has been reported in hapten induced colitis ${ }^{43}$ and in spontaneous colonic inflammation. ${ }^{3-5}$ Colonic permeability to hydrophilic probes is increased in rat (ethanol, acetic acid, and ethanol), guinea pig (carrageenan), and rabbit (immune complex) models of colitis as well as in patients with colitis. ${ }^{404445}$ The concentration of systemic endotoxin, the extent of bacterial translocation, ${ }^{43}$ and degree of colonic permeability correlate with severity of colitis. These findings suggest that translocation of bacteria or bacterial endotoxin and permeability to hydrophilic probes are features of colonic inflammation irrespective of animal species or inducing agent.

The next logical question is whether the increased intestinal permeability and translocation in experimental and clinical IBD is of clinical importance. It has been suggested that translocation of endotoxin and bacteria across the intestinal wall may explain the activation of a systemic inflammatory cascade, disturbances in hepatic function, pathogenesis of abscesses and fistulas, extraintestinal manifestations, and the high incidence of sepsis after elective surgery in patients with IBD. ${ }^{3-57-9} 1314$ Indeed, there is evidence that systemic endotoxaemia correlates with circulating concentrations of cytokines such as tumour necrosis factor and interleukin $6^{46} 47$ and acute phase reactants. ${ }^{10}$ These experimental models of colitis associated with systemic endotoxaemia offer a potential method for discovering the relation between gut derived endotoxin and the systemic inflammatory response.

This study has been presented in part to the IVth International Conference on Endotoxins, Amsterdam 1993.

We wish to acknowledge support from the Eastern Health and Social Services Board, Northern Ireland, The Wellcome and Social Services Board, Northern Ireland, The Wellcome Research Trust, The Royal College of Surgeons of Edinburgh
(Ethicon Foundation), and The Queen's University of Belfast (Ethicon Foundation), and The Queen's University of Belfast
(Samueal Haslett Browne Travelling Fellowship). We thank (Samueal Haslett Browne Travelling Fellowship). We thank
Mervyn McCaigue, PhD and Pauline Erwin, BSc for their help with the endotoxin assay.

1 Keighley MRB, Arabi Y, Dimock F, Burdon DW, Allan $\mathrm{RN}$, Alexander-Williams J. Influence of inflammatory bowel disease on the intestinal microflora. Gut 1978; 19: 1099-104.

2 Dickinson RJ, Varian SA, Axon ATR, Cooke EM. Increased incidence of faecal coliforms with in vitro adhesive and invasive properties in patients with ulcerative colitis. Gut 1980; 21: 787-92.

3 Eade MN, Brooke BN. Portal bacteraemia in cases of ulcerative colitis submitted to colectomy. Lancet 1969; i: ative colitis

4 Ambrose NS, Johnson M, Burdon DW, Keighley MRB. Endogenous intraperitoneal contamination without enterotomy in surgery for Crohn's disease. $B r \mathcal{F}$ Surg enterotomy in

5 Ambrose NS, Johnson M, Burdon DW, Keighley MRB. Incidence of pathogenic bacteria from mesenteric lymph nodes and ileal serosa during Crohn's disease surgery. Br $\mathcal{H}$ Surg 1984; 71: 623-5.

6 Matthews N, Mayberry JF, Rhodes J, Neale L, Munro J, Wensinck F, et al. Agglutinins to bacteria in Crohn's disease. Gut 1980; 21: 376-80.

7 Aoki K. A study of endotoxaemia in ulcerative colitis and Crohn's disease. I. Clinical study. Acta Med Okayama 1978; 32: 147-58.

8 Colin R, Grancher T, Lemeland J-F, Hecketsweiler P, Galmiche JP, Le Grix A, et al. Recherche d'une endotoxinemie dans les entero-colities inflammatoires cryptotoxinemie dans les entero-colities inflammatoires genetiques. Gastroenterol Clin Biol 1979; 3: 15-9.
9 Wellmann W, Fink PC, Benner F, Schmidt FW.
Endotoxaemia in active Crohn's disease. Treatment with Endotoxaemia in active Crohn's disease. Treatment with
whole gut irrigation and 5-aminosalicylic acid. Gut 1986; 27: 814-20. 
10 Gardiner KR, Barclay GR, McCaigue MD, Erwin PJ, Stephens S, Halliday MI, et al. The significance of systemic endotoxaemia in inflammatory bowel disease. Gut 1995; 36: 897-901.

11 Kruis W, Schussler P, Weinzierl M, Galanos C, Eisenburg J. Circulating lipid A antibodies despite absence of systemic endotoxemia in patients with Crohn's disease. Dig Dis Sci 1984; 29: 502-7.

12 Sartor RB, Cleland DR, Catalano CJ, Schwab JH. Serum antibody to bacterial cell wall peptidoglycan in inflammatory bowel disease patients. Gastroenterology 1985; 88: $1571 \mathrm{~A}$.

$13 \mathrm{Liehr} \mathrm{H}$. The limulus assay for endotoxaemia as applied in gastroenterology. In: E Cohen, ed. Biomedical applications of the horseshoe crab (Limulidae). New York: Liss, 1979: 309-20.

14 Nolan JP. Endotoxin, reticuloendothelial function and liver injury. Hepatology 1981; 1: 458-65.

15 Magliulo E, Scevola D, Fumarola D. Limulus test in Escherichia coli enteritis. Lancet 1975; i: 407

16 Brock-Utne JG, Gaffin SL. Endotoxins and anti-endotoxins (their relevance to the anaesthetist and the intensive care specialist). Anaesth Intensive Care 1989; 17: 49-55.

17 Kiss A, Ferenci P, Graninger W, Pamperl H, Potzi R, Meryn S. Endotoxaemia following colonoscopy. Endoscopy 1983; 15: 24-6.

18 Fossard DP, Kakkar VV. The Limulus test in experimental and clinical endotoxaemia. Br $\mathcal{F}$ Surg $1974 ; 61$ : 798-804.

19 Cuevas $P$, Fine J. Demonstration of a lethal endotoxemia in experimental occlusion of the superior mesenteric artery. Surg Gynecol Obstet 1971; 133: 81-3.

20 Jenkins RT, Goodacre RL, Rooney PJ, Bienenstock J Sivakumaran T, Walker WHC. Studies of intestinal permeability in inflammatory diseases using polyethylen glycol 400. Clin Biochem 1986; 19: 298-302.

21 Gardiner KR, Anderson NH, McCaigue MD, Erwin PJ, Halliday MI, Rowlands BJ. Adsorbents as anti-endotoxin agents in experimental colitis. Gut 1993; 34: 51-5.

22 Shorter RG, Huizenga KA, Spencer RJ. A working hypothesis for the etiology and pathogenesis of nonspecific inflammatory bowel disease. Am $尹$ Dig Dis 1972; 17: inflamma 1024 .

23 Kirsner JB, Shorter RG. Recent developments in nonspecific inflammatory bowel disease. $N$ Engl f Med 1982; 306: $837-48$.

24 Fordtran JS, Rector FC, Locklear TW, Ewton MF. Water and solute movement in the small intestine of patients with sprue. $\mathcal{f}$ Clin Invest 1967 ; 46: 287-98.

25 Berg RD, Garlington AW. Translocation of certain indigenous bacteria from the gastrointestinal tract to the mesenteric lymph nodes and other organs in a gnotobiotic mouse model. Infect Immun 1979; 23: 403-11.

26 Morris GP, Beck PL, Herridge MS, Depew WT, Szewczuk MR, Wallace JL. Hapten-induced model of chronic inflammation and ulceration in the rat colon. inflammation and ulceration in

27 Boughton-Smith NK, Wallace JL, Morris GP, Whittle BJR. The effect of anti-inflammatory drugs on eicosanoid formation in a chronic model of inflammatory bowel disease in the rat. $B r \mathcal{F}$ Pharmacol 1988; 94: 65-72.

28 Rachmilewitz D, Simon PL, Schwartz LW, Griswold DE, Fondacaro JD, Wasserman MA. Inflammatory mediators of experimental colitis in rats. Gastroenterology 1989; 97: 326-37.

29 Vilaseca J, Salas A, Guarner F, Rodríguez R, Martínez M, Malagelada J-R. Dietary fish oil reduces progression of chronic inflammatory lesions in a rat model of granulomatous colitis. Gut 1990; 31: 539-44.
30 Psaila JV, Myers B, Jones IR, Rhodes J. Effect of prostaglandin PGE2 in alcohol-induced ulceration in the rat colon. Digestion 1986; 35: 224-8.

31 MacPherson BR, Pfeiffer CJ. Experimental production of diffuse colitis in rats. Digestion 1978; 17: 135-50.

32 Aoki K. A study of endotoxemia in ulcerative colitis and Crohn's disease. II. Experimental study. Acta Med Okayama 1978; 32: 207-16.

33 Hotta T, Yoshida N, Yoshikawa T, Sugino S, Kondo $M$. Lipopolysaccharide-induced colitis in rabbits. Res Exp Med 1986; 186: 61-9.

34 Wessels BC, Gaffin SL. Anti-endotoxin immunotherapy for canine parvovirus endotoxaemia. $\mathcal{f}$ Small Anim Pract 1986; 27: 609-15.

35 Chadwick VS, Phillips SF, Hofman AF. Measurements of intestinal permeability using low molecular weight polyethylene glycols (PEG 400). I. Chemical analysis and polyethylene glycols (PEG 400). I. Chemical analysis and 73: 241-6.

36 Seidman EG, Hanson DG, Walker WA. Increased permeability to polyethylene glycol 4000 in rabbits with experimental colitis. Gastroenterology 1986; 90: 120-6.

37 Delahunty $T$, Recher L, Hollander D. Intestinal permeability changes in rodents: a possible mechanism for degraded carrageenan-induced colitis. Food Chem Toxicol 1987; 25: 113-8.

38 Chadwick VS, Gaginella TS, Carlson GL, Debongnie JC, Phillips SF, Hofmann AF. Effect of molecular structure on bile acid induced alterations in absorptive function, permeability, and morphology in perfused rabbit colon. permeability, and morphology in

39 Gaginella TS, Chadwick VS, Debongie J-C, Lewis JC Phillips SF. Perfusion of rabbit colon with ricinoleic acid dose-related mucosal injury, fluid secretion, and increased permeability. Gastroenterology 1977; 73: 95-101.

40 Jenkins RT, Jones DB, Goodacre RL, Collins SM, Coates G, Hunt RH, et al. Reversibility of increased intestinal permeability to ${ }^{51} \mathrm{Cr}$-EDTA in patients with gastrointestinal inflammatory disease. Am F Gastroenterol 1987; 82: 1159-64.

41 Casellas F, Aguade S, Soriano B, Accarino A, Molero J, Guarner L. Intestinal permeability to $99 \mathrm{mTC}$ DPTA in inflammatory bowel disease. Am ₹ Gastroenterol 1986; 81: 767-70.

42 Gomes M de FA, Dunne J, Logan LH, Pounder RE. Noninvasive assessment of small intestinal damage in Crohn's disease and ulcerative colitis. Gut 1983; 24: 486A

43 Gardiner KR, Erwin PJ, Anderson NH, Barr JG, Halliday MI, Rowlands BJ. Colonic bacteria and bacterial translocation in experimental colitis. Br f Surg 1993; 80: 512-6.

44 Rask-Madsen J, Hammersgaard EA, Knudson E. Rectal electrolyte transport and mucosal permeability in ulcerative colitis and Crohn's disease. $\mathcal{f}$ Lab Clin Med 1973; 81: 342-53.

45 O'Morain CA, Abelow AC, Chervu LR, Fleischner GM, Das KM. Chromium 51-ethylenediaminetetraacetate test: a useful test in the assessment of inflammatory bowel disease. F Lab Clin Med 1986; 108: 430-5.

46 Gardiner KR, Halliday MI, Lloyd F, Stephens S, Rowlands BJ. Circulating tumour necrosis factor in active inflammatory bowel disease. In: Faist E, Meakins J L, Schildberg $\mathrm{F} \mathrm{W}$, eds. Host defense dysfunction in trauma, shock and sepsis. Berlin: Springer-Verlag, 1993; 699-703.

47 Mahida YR, Kurlak L, Hawkey CJ. High circulating concentrations of interleukin-6 (IL-6) in active Crohn's disease but not ulcerative colitis. Gut 1991; 32: 1531-4. 